\title{
Molecular diagnosis of genodermatoses in india
}

\author{
Parag Tamhankar \\ From International Conference on Human Genetics and 39th Annual Meeting of the Indian Society of \\ Human Genetics (ISHG) \\ Ahmadabad, India. 23-25 January 2013
}

Genodermatoses refer to inherited diseases of skin structure and function. Several genodermatoses present with multisystem involvement lead to increased morbidity and mortality. Genetic Research Centre focused on identifying molecular basis of such dreadful skin diseases with recessive inheritance. This would help us identify common mutations, founder effects etc that would reduce the cost of screening patients and their carrier parents. During the years 2011-13, 100 patients were referred to the centre with genodermatoses. The commonest group was ichthyosis followed by epidermolysis bullosa, ectodermal dysplasia, albinism, cutis laxa, progeroid conditions, precancerous conditions xeroderma pigmentosum, Rothmund Thomson syndrome, dyskeratosis congenita. Genetic heterogeneity is very common and molecular diagnosis requires an extensive effort. Recurrent mutations in unrelated families were seen in families with xeroderma, Griscelli. Prenatal diagnosis could be provided for ichthyosis, infantile hyalinosis and progeria. This is the largest cohort of mutation proven patients with genodermatoses from India.

Published: 21 January 2014

Submit your next manuscript to BioMed Central and take full advantage of:

- Convenient online submission

- Thorough peer review

- No space constraints or color figure charges

- Immediate publication on acceptance

- Inclusion in PubMed, CAS, Scopus and Google Scholar

- Research which is freely available for redistribution



(C) 2014 Tamhankar; licensee BioMed Central Ltd. This is an Open Access article distributed under the terms of the Creative Commons Attribution License (http://creativecommons.org/licenses/by/2.0), which permits unrestricted use, distribution, and reproduction in any medium, provided the original work is properly cited. The Creative Commons Public Domain Dedication waiver (http:// creativecommons.org/publicdomain/zero/1.0/) applies to the data made available in this article, unless otherwise stated. 